\title{
A day in the life of a genome biologist in the not-too-distant future Gregory A Petsko
}

Address: Rosenstiel Basic Medical Sciences Research Center, Brandeis University, Waltham, MA 02454-9110, USA.

Email: petsko@brandeis.edu

Published: 29 March 2007

Genome Biology 2007, 8:104 (doi:10.1186/gb-2007-8-3-104)

The electronic version of this article is the complete one and can be

found online at http://genomebiology.com/2007/8/3/104

(C) 2007 BioMed Central Ltd

\begin{abstract}
Megalopolis, United States of Western Hemisphere, 18 June 2273. The following fragment was uncovered in an underwater archaeological dig, on the site now generally believed to be the location of the almost mythical engineering school, Screwloose La Tech. Ever since global warming led to the flooding of the entire Eastern Seaboard of North America in 2138, artifacts from the Cambrian Period, as the period of the great universities in Cambridge is called, have been very hard to come by. This document is therefore of great historical significance. Nothing is known about the writer, except that similarities of style suggest that he may actually have been the same as the master of the Genome Biology columns, whose work has recently been challenged as fraudulent.
\end{abstract}

Pursuant to Federal Paperwork Reduction Act 3,671 of 2016, herewith is submitted daily activities report for Saturday, 3 June 2030.

7:44 am to 8:02 am. Arrived shuttle parking lot number 4 , located 11.25 miles from campus. Turned off motor on electric car and detached mandatory passive restraint devices (seat belt, shoulder harness, neck brace, ankle restraints and wrist locks) before exiting. Plugged battery cord into recharger built into parking meter. Inserted \$255 in five dollar coins to cover daily parking and battery charging costs. [Personal note: must remember to get more five dollar coins from bank. Ever since university raised off-campus parking fees for faculty to $\$ 41,000$ per year, have been lugging around more bags of coins than an armored car.] Waited 30 minutes for shuttle bus to campus.

8:46 am to 9:27 am. Arrived at office. Couldn't unlock door because minor head cold has altered appearance of eyes and eyeball-scanner security device couldn't recognize them. Waited 30 minutes for campus swat team to respond to security alarm and unlock door.
9:28 am to 11:11 am. Turned on computer and checked email. Only 1,459 new messages since last night. Ran new Microsoft anti-spam program, which automatically deleted 832 of them, including message from mother. Ran newer Microsoft anti-spam bug fixer, which restored message from mother and other 831 junk messages, plus 204 new junk messages it found from somewhere. Switched to personal examination of messages. Found that only two messages actually were important; all others were spam, including message from mother.

11:12 am to 11:54 am. Surprise inspection by agents from Government Office for Toxicity Checking and Hazard Assessment (GOTCHA). Examined all labs-on-chips at every student desk-bench. Found four minor violations (two chips were not dusted and the dust from two others was not properly collected and stored). Ever since scientific responsibility for wrongdoing (SCREW) mandate of 2020, signed into law by President George IJK Bush IV, scientist responsible for laboratory must pay fines for any GOTCHA violations immediately from personal funds. Presented debit card to agents for fines of $\$ 4,400$ ( $\$ 1,100$ per violation). Oh well, still a lot better than last week.

11:55 am to 12:39 pm. Met with two students from advanced genomic, cell, molecular and psychological neurosociobiology course. Listened to complaints about their midterm grade. Students argued that grade of A+++, well below class average, severely hampered their ability to gain admission to medical school and therefore constituted grievous psychological harm. Threatened to inflict equivalent grievous bodily harm unless I changed grades. Ever since mandatory American national interpersonal armament concealment (MANIAC) statute law, signed by President George LMN Bush V, required that all citizens carry concealed weapons at all times, such student-faculty disputes have become easier to resolve. Started reaching for pocket grenade launcher but then considered that odds of 
2-against-1 dictated non-violent response. Changed grades to class average of Super-A+++++++.

12:40 pm to 12:45 am. Ate lunch, which as always consisted of trans-fat sandwich on tobacco leaf bread. Paused to reflect how amazing that earlier generations of scientists actually considered this unhealthy - exactly the opposite of what careful research has now shown.

12:45 pm to 1:56 am. Reviewed results of latest genome sequencing project in the lab. Sequence of gerbil genome, begun at 12 noon, now complete. Immediately entered file of results into Microsoft Office 2025, which immediately crashed after erasing file. Restored file from backup microdot and relaunched program, which proceeded to write paper describing results, including changing spelling of my name to something it liked better. Attempted to change name back only to be told by the program that it was smarter than me, always would be smarter than me, and that I should go away and let my betters do their job. [Personal note: visit district court and change spelling of my name to that used by program].

1:56 am to 2:39 pm. Submitted finished manuscript, with Bill Gates III first author, as he is on all papers everywhere, to Nature Gerbil, Gerbil Cell, Gerbil Genome Biology, PloS Gerbil, and Current Gerbil Biology. (Ever since famous Supreme Court decision in case of J Craig Venter vs Nature, Science and Cell, scientists have had the right to submit their papers simultaneously to as many journals as they like, and to have the same paper published in up to five journals at once.) Since the Harold Varmus overthrow of capitolism (HAVOC) Act of 2011 made it illegal for journals to reject papers or to make a profit, all journals now accept all papers automatically so paper was immediately accepted by all five. Should appear on-line sometime in 2037 if the backlog doesn't get worse.

2:39 am to 3:55 pm. Attended mandatory daily sensitivity training workshop, required of all faculty by the Office of Self-Esteem, which has controlled all US universities since the Political Correctness Wars of 2014. Was reminded yet again that any idea, no matter how idiotic, must be respected since to do otherwise would stifle student creativity and self-expression.

3:55 pm to 4:00 pm. Thought about meaning of results of research.

4:00 pm to 6:15 pm. Realized I had forgotten to check e-mail for several hours. Found 2,651 new messages. Not bad. Deleted all except offer from ex-Nigerian government official who wants to give me $\$ 24$ billion in return for promise to think happy thoughts about him. Must look into this tomorrow.
6:15 pm to 7 pm. Packed up to go home. Waited 45 minutes for shuttle bus to parking lot. While waiting, checked latest news on iPhone. Still no progress on ending war in Iraq. 